\title{
Comparative evaluation of COVID-19 pandemic enforced online teaching versus traditional teaching from point of view of medical students
}

\author{
Radhika Vijay* \\ Department of Pharmacology, S. P. Medical College, Bikaner, Rajasthan, India
}

Received: 26 October 2020

Revised: 26 November 2020

Accepted: 30 November 2020

*Correspondence:

Dr. Radhika Vijay,

Email: drradhika_vijay@yahoo.in

Copyright: ( $\odot$ the author(s), publisher and licensee Medip Academy. This is an open-access article distributed under the terms of the Creative Commons Attribution Non-Commercial License, which permits unrestricted non-commercial use, distribution, and reproduction in any medium, provided the original work is properly cited.

\begin{abstract}
Background: The current ongoing coronavirus-2019 (COVID-19) pandemic has brought a sea change in education teaching learning system, ways and methodologies. Online teaching has been enforced suddenly for students worldwide. It has become a substitute to traditional teaching. Aware of the fact that the Corona pandemic has changed the way of learning teaching, we want to find out what students think about their real predispositions. This study is to compare and evaluate the opinions, preferences, experiences of undergraduate medical students during continuous online classes since the onset of Pandemic times.

Methods: A sample size of 115 undergraduate medical students of batch 2019 was taken for the study done in Sardar Patel Medical College of Bikaner, Rajasthan, India in October 2020.A questionnaire was prepared using Google forms application and was filled by students online.

Results: Majority of students had a preference and interest for traditional mode of teaching, they agreed on better understanding of concepts and details of topic and grasping more of knowledge through it. But majority of students also agreed that they are getting more time to study now with online teaching.

Conclusions: This study gives an in depth insight into the current ongoing online teaching methodologies and throws light on changing acceptance of students to the current COVID-19 pandemic ways of teaching and on welcoming a better "blended learning" pattern in the upcoming Post COVID-19 new normal times.
\end{abstract}

Keywords: COVID-19 pandemic, Online teaching methods, Traditional teaching methods, Blended learning

\section{INTRODUCTION}

The current ongoing coronavirus-2019 (COVID-19) pandemic has brought a sea change in education teaching learning system, ways and methodologies. Online teaching has been suddenly enforced for the students worldwide. It has become a substitute to traditional teaching. Aware of fact that Corona pandemic has changed the way of learning teaching, we want to find out what students think their real predispositions education can become transformative when students and teachers synthesize different perspectives, incorporate various inquiries. Such possibilities are constructed by fostering critical learning spaces. Students should be encouraged to increase their capacities of analysis, imagination, critical synthesis, creative expression, self-awareness and intentionality.

History is evident of the fact that the conversion of face to face to online teaching has not happened overnight. ${ }^{1}$ Isaac et al in 1996 said that distance education is no more than hodgepodge of ideas, practices taken from traditional classroom settings and imposed on learner who just happens to be separated physically from an instructor. ${ }^{1}$ 
Online education is defined as any curriculum delivered to a student separated by time or space from an instructor. ${ }^{2}$

Need of online education was also identified by Kearsley in their study. Finch et al stated advantages of online teaching, education in their study. ${ }^{1}$

Christner 2003 indicates distance education was known as far back as in the mid 19th century as "corresponding courses" 3 . The number of students enrolled in online courses has more than doubled in the past 5 years (Roman 2006)2. Literature shows that traditional institutes are now becoming hybrid institutes now (Carlson, Cheng). ${ }^{4,5}$

Online education began late in 20th century via synchronous chat rooms, messaging, texting, etc. Invention of @ symbol in 1972 (Krichmar et al) and advent of world wide web (www) in 1991 for Internet connectivity (Harasim) are latest adaptations in online development. Wide use of emails, conferencing, chatting, Google drive, Google doc, Google hangout, dropbox, facebook, twitter is being done now in classrooms. ${ }^{1}$

Fast development of the world wide web has produced numerous benefits to education. Online education provides potential opportunities to open up new markets for higher education. Adult learners enjoy flexibility in balancing work, study and family routines. Various technology advancements enhance interaction among students and instructors at large.

It is a boon for shy personalities, everything can be done online- data collection, feedback, evaluation of online education experience. ${ }^{1}$

Literature and previous studies suggest non-traditional students value flexibility of online classes, appreciate prompt feedback from faculty and valued group projects and discussion (Miller et al). ${ }^{6}$ E learning will soon have use everywhere, it is important to get a student's opinion and attitudes and opportunities. Understanding current scenario of medical teaching, learning in COVID-19 pandemic research in academics and clinics may greatly help in improving teaching. ${ }^{7}$

Several studies on students' perceptions documented improvement in students performance through improved teaching and learning processes. ${ }^{7-11}$

Survey was done by the Department of Political Science at MSU. The majority of students and teachers were dissatisfied with online classes during the past two months in lockdown. ${ }^{12}$ Online mode has to be affordable, inclusive and democratic. ${ }^{12}$

Online teaching and learning may have lasting positive effects, open interesting possibilities for innovation, new ways of working especially if supported by appropriate and timely professional development. ${ }^{13}$ This study is to compare and evaluate the opinions, preferences, experiences of undergraduate medical students during continuous online classes since the onset of pandemic times.

\section{Aim}

To know how many students are interested in online teaching and to gather feedback, opinion and preferences of student.

\section{METHODS}

It is an analytical, descriptive, cross sectional questionnaire-based study. A sample size of 115 undergraduate medical students of batch 2019 was taken for the study done in Sardar Patel Medical College of Bikaner, Rajasthan, India in October 2020.,14. A questionnaire was prepared using Google forms application and was filled by students online. All the students who filled the google form after informed consent were included in the study. Two days duration was given to the students to fill the questionnaire forms after which the Google form was closed by turning the responses off.

Most of the data was automatically made and analysed in pie charts by Google form application, although it was also separately entered in Microsoft excel to analyse and sort out as different tables and charts pertaining to different questions and sections of the study.

Different variables like age, learning mode preferences, use of headphones, effects on writing skills, level of knowledge gained, time for study, adverse effects were studied. Overall student's perception, experience and feedback was analysed.

The questionnaire was prepared in English language. It was broadly divided in three parts. The first part consisted of informed consent in form of question one. Second part comprised of student details like name, age and sex. Lastly, the third part contained detailed study questions about student's perception, experience and opinion regarding current ongoing pandemic enforced online teaching and classes compared to traditional teaching methods.

There were 18 questions, question 1 was to take informed consent of the individual and was mandatory. Question 2 to 4 were to ask for student details and were also mandatory. Question 5 to 17 were optional questions related to study and question 18 was to rate overall experience of online classes and was mandatory (Table 1). Types of questions were short answer type, multiple choice (single answer) yes/no type, and tick box type (multiple answers).

\section{Inclusion criteria}

Sample size of 115 was considered from first year undergraduate medical students' of 2019 batch of Sardar 
Patel Medical College Bikaner, Rajasthan, India. It consisted of all male and female students who received Google form questionnaire via wats app application on mobile phone and all students who filled and submitted their responses after giving informed consent within 2 days time period.

\section{Exclusion criteria}

All the students (male/ female) who did not receive the Google form questionnaire, who did not complete or submit their response within 2 days time period and who did not give informed consent were not included in the study.

Table 1: Questionnaire form and questions asked to the students (without answer options).

\begin{tabular}{|c|c|}
\hline S no & Questionnaire \\
\hline 1 & Informed Consent \\
\hline 2 & Name of Student \\
\hline 3 & Age of student \\
\hline 4 & Male/Female \\
\hline 5 & What is your preferred mode of teaching? \\
\hline 6 & $\begin{array}{l}\text { Do you think you can study more or grasp } \\
\text { more through online class? }\end{array}$ \\
\hline 7 & Is it stressful to attend online class? \\
\hline 8 & $\begin{array}{l}\text { Is your discipline level decreased due to online } \\
\text { class? }\end{array}$ \\
\hline 9 & $\begin{array}{l}\text { After pandemic ends, what is your choice of } \\
\text { mode of teaching? }\end{array}$ \\
\hline 10 & $\begin{array}{l}\text { Do you think online teaching is temporary } \\
\text { arrangement mode of teaching? }\end{array}$ \\
\hline 11 & $\begin{array}{l}\text { Do you think online class offers in depth } \\
\text { knowledge of topic? }\end{array}$ \\
\hline 12 & $\begin{array}{l}\text { Do you think time restraint in traditional mode } \\
\text { of teaching decreases its potency? }\end{array}$ \\
\hline 13 & $\begin{array}{l}\text { What physical symptoms did you notice in } \\
\text { yourself after start of pure online classes } \\
\text { during pandemic? }\end{array}$ \\
\hline 14 & Do you use headphones to attend online class? \\
\hline 15 & $\begin{array}{l}\text { Has online classes affected your writing speed } \\
\text { and ability negatively? }\end{array}$ \\
\hline 16 & Do you get more time to study now? \\
\hline 17 & Your favorite online way of learning? \\
\hline 18 & Rate online class experience? \\
\hline
\end{tabular}

\section{Data analysis}

The answers of questions were reported as percentages in form of pie charts automated by google form response analysis system. Later manually data was entered in excel sheets to build up different and sorted out charts and tables.

\section{RESULTS}

\section{Demographic variables of participating students}

All in all 115 students participated in this study. Amongst them $78(67.8 \%)$ were males and $37(32.2 \%)$ were females. $45(39.1 \%)$ students were of age 20 years (maximum) and $1(0.9 \%)$ student was of 25 years (minimum) age. Average age of sample was 16.234 (Table 2).

\section{Student's comparative opinions and preferences regarding online versus traditional teaching}

In these set of questions, the comparative points from student's opinions about online versus traditional teaching methods were taken into consideration related to their preferences, their grasping power, thoughts about current online classes, coverage of topic in depth, time restraint in traditional teaching and opinion about post COVID teaching learning strategies (Table 3).

Students were asked about the different preferences regarding mode of teaching, total 114 responses were obtained. 57 students (50\%) voted for traditional method of teaching, in this case referring to chalk and blackboard method. 45 students $(39.5 \%)$ voted for mixed mode or blended methodology of teaching referring here to a combination of virtual and traditional mode of teaching. While only 12 students $(10.5 \%)$ voted for pure virtual teaching methods referring here to pure online teaching methodology.

Students were asked if they could grasp more via online classes as compared to traditional teaching methods, then 114 responses were obtained. 58 students $(50.9 \%)$ replied a "no" to this question. 34 students $(29.8 \%)$ replied "sometimes" to his question while only 22 students $(19.3 \%)$ replied a "yes" to this question.

Student's opinion was sought as if they think that online mode of teaching is simply a temporary arrangement during Corona times, for this question, 114 responses were received. 58 students $(50.9 \%)$ agreed to this question in response and said a "yes". 37 students $(32.5 \%)$ were really not sure and ticked the option "maybe" and only 19 students $(16.7 \%)$ disagreed to the question asked and ticked a "no".

Students were asked regarding their opinion if they think that online classes are more elaborative and descriptive offering a better insight into the topic's depth. For this, 110 responses were received, out of which 90 students $(81.8 \%)$ strongly disagreed and ticked a "no" while only 20 students $(18.2 \%)$ agreed and said "yes".

Student's opinion was sought to know if time restraint in traditional method of teaching is responsible to decrease its 
potency as compared to online mode of teaching where there is no time limit of class content. For this, out of 104 responses obtained, 54 students $(51.9 \%)$ agreed and voted a "yes", while rest 50 students (48.1\%) disagreed and voted a "no".

Table 2: Percentage of male/female students who participated in the study.

\begin{tabular}{|ll|}
\hline Male/Female & Percentage \\
\hline Male students & $67.8 \%$ \\
\hline Female students & $32.2 \%$ \\
\hline
\end{tabular}

Table 3: Comparative evaluation of online versus traditional teaching methods from point of view of medical students.

\begin{tabular}{|c|c|c|c|}
\hline Question & $\begin{array}{l}\text { Online } \\
\text { teaching } \\
\text { methods }\end{array}$ & $\begin{array}{l}\text { Traditio } \\
\text { nal } \\
\text { teaching } \\
\text { methods }\end{array}$ & Other \\
\hline $\begin{array}{l}\text { Preferred } \\
\text { mode of } \\
\text { teaching } \\
\text { learning }\end{array}$ & $10.5 \%$ & $50 \%$ & $\begin{array}{l}39.5 \% \\
\text { vote for } \\
\text { hybrid } \\
\text { teaching } \\
\text { methods }\end{array}$ \\
\hline $\begin{array}{l}\text { Learning or } \\
\text { grasping of } \\
\text { Knowledge }\end{array}$ & $19.3 \%$ & $50.9 \%$ & $\begin{array}{l}29.8 \% \\
\text { voted } \\
\text { "sometime } \\
\text { s" option }\end{array}$ \\
\hline $\begin{array}{l}\text { Longevity of } \\
\text { which mode } \\
\text { of teaching } \\
\text { learning }\end{array}$ & $16.7 \%$ & $50.9 \%$ & $\begin{array}{l}32.5 \% \\
\text { voted for } \\
\text { "maybe } \\
\text { "option }\end{array}$ \\
\hline $\begin{array}{l}\text { Greater } \\
\text { insight into } \\
\text { topic in } \\
\text { depth }\end{array}$ & $18.2 \%$ & $81.8 \%$ & \\
\hline $\begin{array}{l}\text { Time } \\
\text { restraint } \\
\text { decreases } \\
\text { potency of } \\
\text { class }\end{array}$ & & $\begin{array}{l}51.9 \% \\
\text { agreed }\end{array}$ & $\begin{array}{l}48.1 \% \\
\text { disagreed }\end{array}$ \\
\hline $\begin{array}{l}\text { Post } \\
\text { COVID } 19 \\
\text { preferred } \\
\text { teaching } \\
\text { mode }\end{array}$ & $3.5 \%$ & $41.2 \%$ & $\begin{array}{l}55.3 \% \\
\text { opted for } \\
\text { mixed i.e. } \\
\text { Blended } \\
\text { mode of } \\
\text { teaching }\end{array}$ \\
\hline
\end{tabular}

Finally, the most awaited question was asked to the students that what would be there preferred mode of teaching-learning in post COVID-19 pandemic new normal classes. For this question 114 responses were received, out of which 63 students $(55.3 \%)$ opted for a mix of both virtual and traditional class systems, i.e. blended learning. 47 students (41.2\%) opted for same old pure traditional method of teaching and only 4 students $(3.5 \%)$ opted for pure online classes methodology.

\section{Student's experience with online classes in COVID-19 pandemic times so far}

In this set of questions, students were analysed for different experiences like stress, discipline level, writing speed, use of headphones, and their favorite online mode of learning. (Table 4)

Table 4: Students overall experience of online classes.

\begin{tabular}{|lcrl|}
\hline $\begin{array}{l}\text { Questions } \\
\text { Yes }\end{array}$ & No & Other \\
\hline $\begin{array}{l}\text { Are online classes } \\
\text { stressful? }\end{array}$ & $63.2 \%$ & $36.8 \%$ & \\
\hline $\begin{array}{l}\text { Is discipline level } \\
\text { decreased due to } \\
\text { online classes? }\end{array}$ & $55.4 \%$ & $20.5 \%$ & $\begin{array}{l}24.1 \% \\
\text { voted for } \\
\text { "sometime } \\
\text { s" }\end{array}$ \\
\hline $\begin{array}{l}\text { Did you notice } \\
\text { adverse effect on } \\
\text { writing speed and } \\
\text { ability? }\end{array}$ & $54.4 \%$ & $25.4 \%$ & $\begin{array}{l}20.2 \% \\
\text { opted for a } \\
\text { "maybe" }\end{array}$ \\
\hline $\begin{array}{l}\text { Do you use } \\
\text { headphones to } \\
\text { attend online } \\
\text { classes? }\end{array}$ & $77.2 \%$ & $22.8 \%$ & \\
\hline $\begin{array}{l}\text { Do you get more } \\
\text { time to study now? }\end{array}$ & $53.6 \%$ & $46.4 \%$ & \\
\hline
\end{tabular}

Students were asked if it was stressful to attend online classes daily, then out of 114 responses received, 72 students $(63.2 \%)$ agreed strongly, ticking a "yes", while 42 students $(36.8 \%)$ disagreed and ticked a "no".

Students were asked to check if there discipline level was affected especially decreased due to continuous Online classes, then for this 112 responses were obtained, out of which 62 students (55.4\%) agreed well and voted "yes", 27 students $(24.1 \%)$ experienced this problem only "sometimes", and 23 students, $(20.5 \%)$ did not agree at all and voted a "no" option.

Students were asked to let know if there had been any adverse effects on their writing speed, then 114 responses were received, out of which, 62 students (54.4\%) agreed that their speed of writing has decreased by opting for an "yes", 29 students (25.4\%) disagreed saying that there was not any effect on their writing abilities and 23 students (20.2\%) opted for a third option, "maybe".

Students were asked about use of headphones while attending online classes, then out of 114 students who responded, 88 students $(77.2 \%)$ were found to use headphone devices to attend online classes, while 26 students $(22.8 \%)$ were not found to use any such device.

Students were also asked about their preferred rather favorite mode of online class delivery, then amongst 111 responses obtained, 105 students $(94.6 \%)$ opted for video, 
12 students $(10.8 \%)$ opted for slides or ppt, 7 students $(6.3 \%)$ had a preference for documents like doc or pdf files and only 6 students (5.4\%) opted for audio (Figure 1).

Lastly in this set of questions, students were asked to let know if they are getting ample time to study, more as compared to traditional teaching due to online teaching methods, then 110 students responded and amongst them, 59 students $(53.6 \%)$ replied positively with a "yes" option and 51 students $(46.4 \%)$ found no changes in study time due to online classes and opted for a "no".

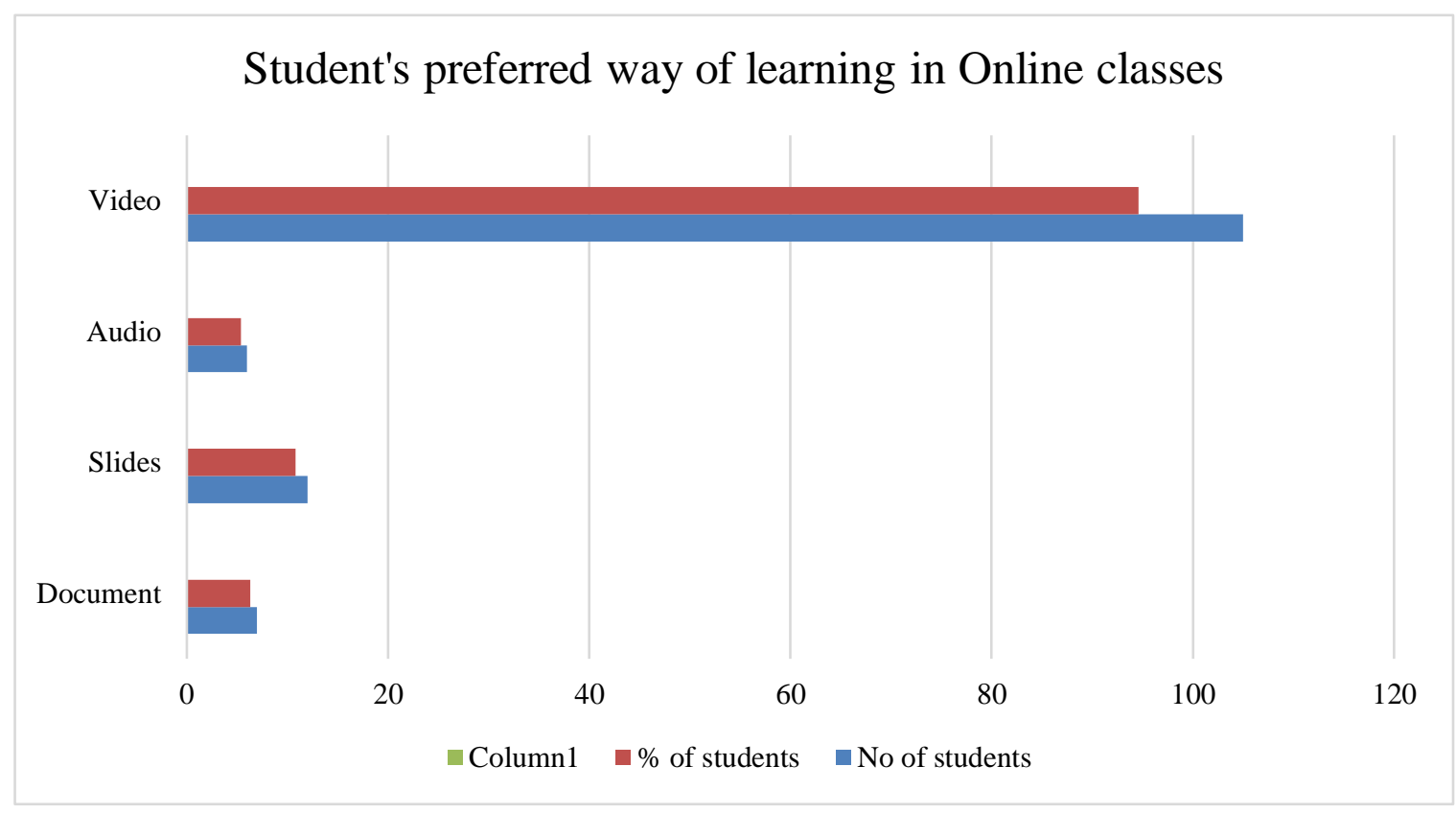

Figure 1: Students preferred way of learning in online classes.

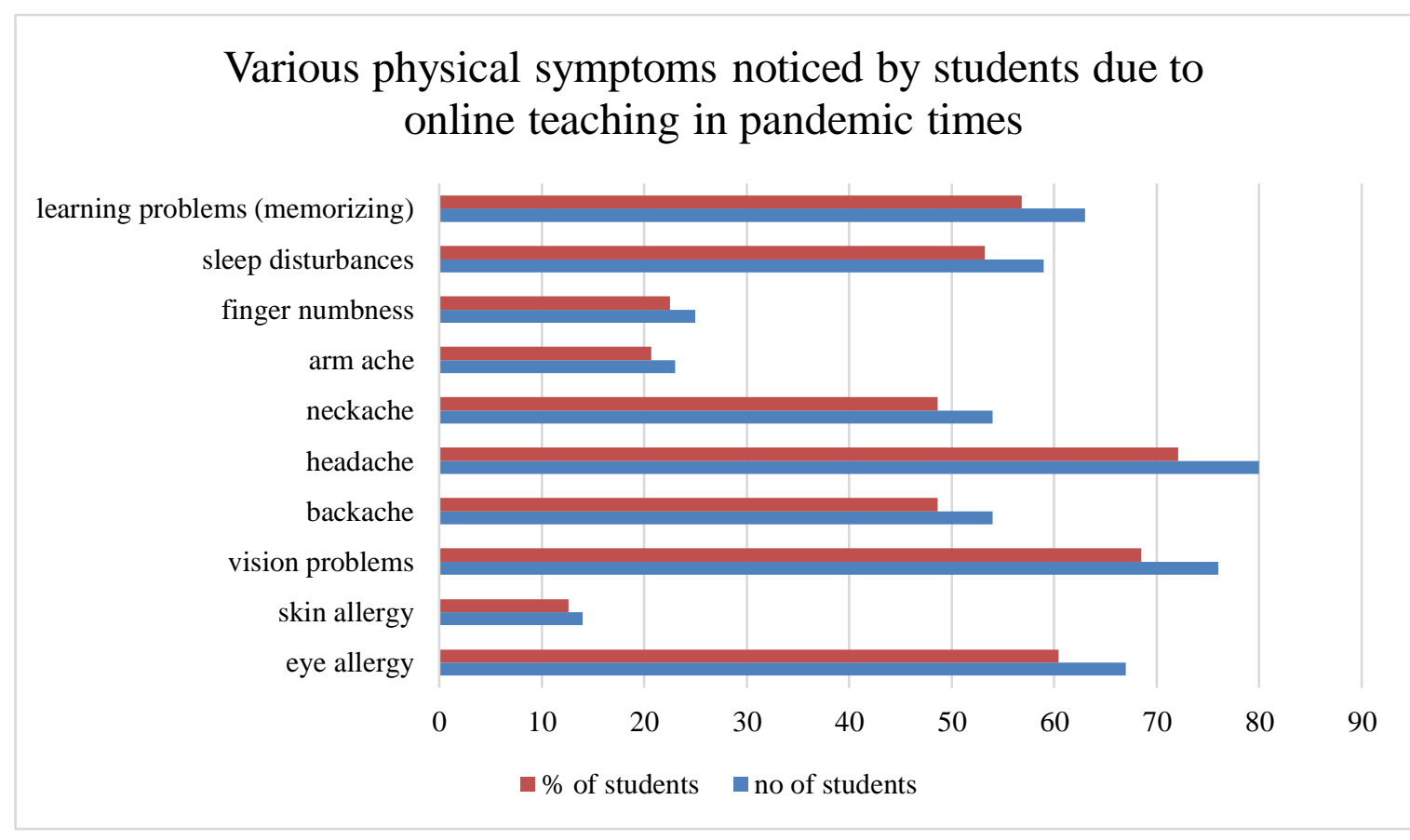

Figure 2: Various physical symptoms experienced by students due to continuous online exposure enforced by COVID-19 pandemic.

Students experience of side effects due to online teaching methods
In this set of questions students were asked to tick whatever physical symptoms they were realising or experiencing due 
to continuous exposure to online classes after onset of COVID-19 Pandemic onset, amongst 111 students who responded, 80 students $(72.1 \%)$ experienced headache, 76 students $(68.5 \%)$ had vision problems enhanced, 67 students $(60.4 \%)$ had eye allergy, 63 students $(56.8 \%)$ had learning or memorising difficulties, 59 students $(53.2 \%)$ had sleep disorders, 54 students $(48.6 \%)$ suffered from neck ache and backache due to postural defects, 25 students (22.5\%) experienced finger numbness, 23 students (20.7\%) had an arm ache and 14 students (12.6\%) experienced certain skin allergic reactions (Figure 2).

Different side effects experienced by students are summarized in a tabular form (Table 3 ).

\section{Students overall rating of online teaching methods}

In the end, a mandatory question was put up to students to rate their overall experience of Online teaching-learning so far from onset of COVID-19 pandemic times, then out of 115 student responses received, 56 students (48.7\%) found it "ok", 29 students $(25.2 \%)$ found it "very bad", 21 students $(18.3 \%)$ found it "good", 9 students $(7.8 \%)$ opted for "Does not matter" and none found it "excellent" (Figure 3 and Table 5).

Table 5: Students rating of online class experience after onset of COVID-19 pandemic.

\begin{tabular}{|l|l|}
\hline Ratings & $\%$ of students \\
\hline Very bad & 25.2 \\
\hline Ok & 48.7 \\
\hline Does not matter & 7.8 \\
\hline Good & 18.3 \\
\hline Excellent & nil \\
\hline
\end{tabular}

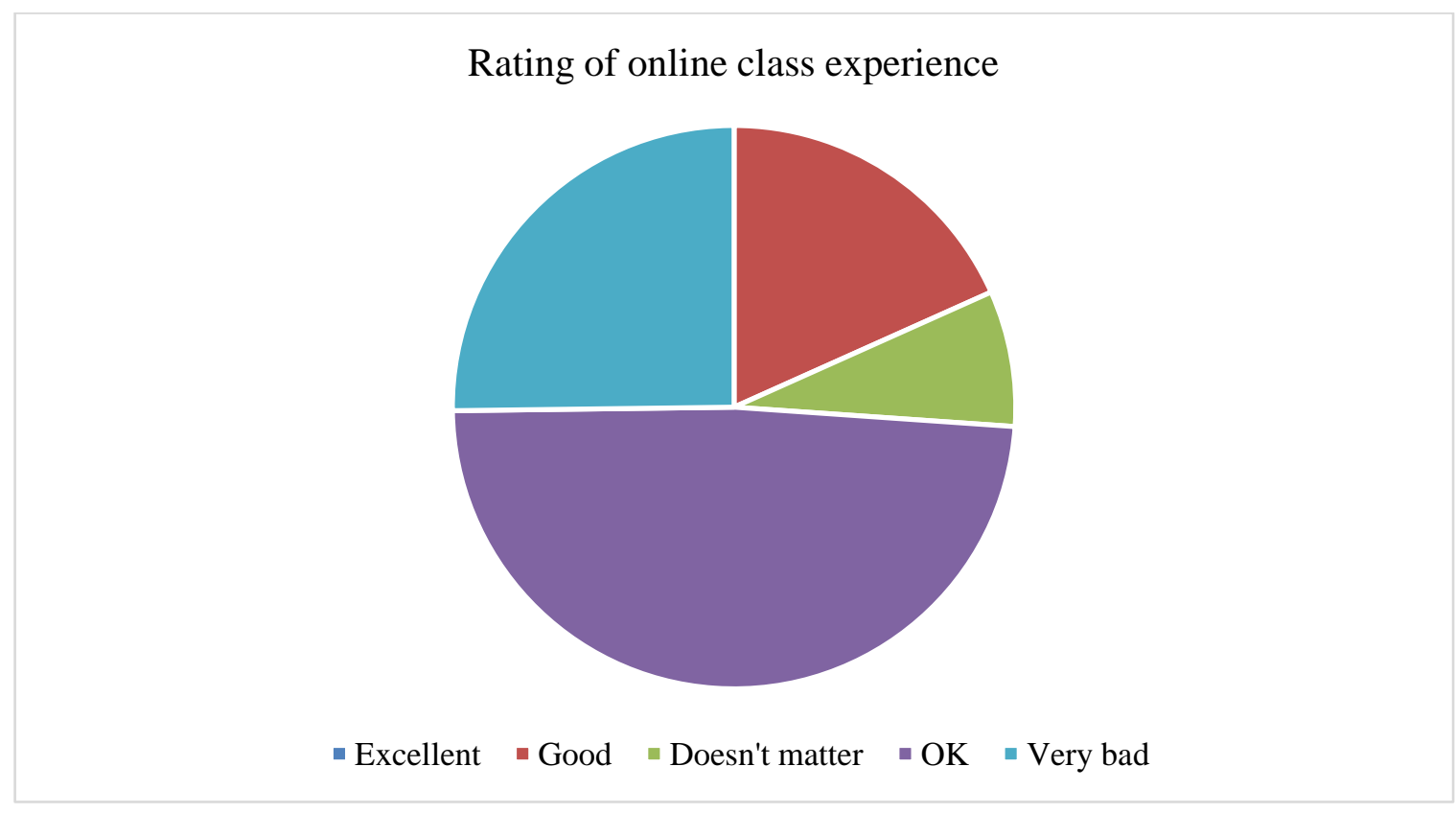

Figure 3: Overall rating of Online class by students experience after start of COVID-19 pandemic.

\section{DISCUSSION}

Student feedback is an effective tool for modification of undergraduate teaching strategies and making them more interesting and practicable, it helps to improve performance when students' suggestions are implemented. ${ }^{7,15}$

In general, students gave authentic opinion, feedback and experience of their sudden online changed mode of learning, it reflects a lot on many unrevealed perspectives of teaching and gives new dimension to overall thinking about education measures and strategies in coming times.
Feedback, opinions and preferences of student reveals whether so called current online class schedules are relevant, acceptable and how and what could be done to better them out. ${ }^{7,16}$

A comparison of students' point of view about online teaching methods versus traditional teaching methods was made by the first set of questions. In 6 questions, a comparative analysis could be made and students' level of convenience and adaptation to this sudden enforced teaching mode was made clear.

Majority of students had a preference and interest for traditional mode of teaching, they agreed on better 
understanding of concepts and details of topic and grasping more of knowledge through traditional methods of teaching and they agreed that online classes are in fact only a temporary mode of teaching just to combat with COVID 19 pandemic times. Opinion was sought regarding post COVID 19 pandemic teaching learning strategy and ways, $55.3 \%$ students opted for option of "Mixed/Hybrid/Blended learning". These findings are similar to the E learning survey done by Zeljka et al to seek students' opinion where $76.07 \%$ students opted for supplementing E teaching with old forms of teaching. ${ }^{14}$ Our results are also similar to the national survey done on undergraduate students during COVID-19 pandemic, "suddenly online", where 51\% were happy and satisfied in courses before turning to online fully. ${ }^{17}$ Regarding time constraint factor in traditional mode of teaching, the majority of students agreed that it was a drawback and it simply shows that Instructors need to plan learning activities that maximise the impact of interactions with students and provide alternative forms of interaction when time constraints become excessive. ${ }^{18} 55.3 \%$ opted for a blended teaching- learning strategy in post COVID-19 new- normal times. This perception of students was the same as in studies by Zeljka et al and Dhami et al., ${ }^{74}$

Second set of questions were asked to gain knowledge of overall experience of students while attending online classes during COVID 19 pandemic. In this, 5 questions were yes /no type and one was regarding the favorite way of online learning. Majority of students agreed that online classes are stressful and they are experiencing a decreased level of discipline since the start of these types of classes on a daily regular basis. Majority of students agree to the fact that they noticed an adverse effect on their writing speed and ability, they used headphones to attend online classes. But more than half of students also agreed that they are getting more time to study now. These results are the same as disadvantages stated by Zeljka et al in their study that in E learning, there is no compulsion of learning and working for long hours is quite harmful. ${ }^{14}$ These were different to problems stated in "suddenly online" studies where biggest challenge of students was loneliness and difficult to stay motivated while studying from online classes and they were also differing from the case study by Tehran where the greatest negatives of online teaching were stated as lack of discussion, incomplete feedback as no audience and more scope of interruption during online classes. $^{2,17}$

As far as preferred way of online learning is concerned, maximum students voted for video format followed by slides or ppt presentation, this result matches with the study by Gillinham, Dhami et al. ${ }^{19,7}$ Online education permits exchange of ideas and information, to work together on projects around the clock from anywhere in the world (Hiltz). ${ }^{20}$

Third set of questions was made to make students tick whatever physical symptoms or changes they were noticing in themselves due to continuously attending online classes, the major complaints in descending order were headache, vision problems, eye allergy, learning problems, sleep disturbances, backache, neckache, finger numbness, arm ache and skin allergy. Such details and specifications were not matching to any of the available studies but Zeljka et al did comment on the importance of health and how online exposure can be harmful for students. $^{14}$

Building an increased internet access and mobile platforms, blended learning, a fusion of both face to face and online learning, enhances quality, equity and lifelong opportunities, these were key goals of UNESCO and the book- blended learning. ${ }^{21}$ Education 2030 aims at ensuring inclusive and equitable and quality education and lifelong learning opportunities across all modes, formal and non formal. Blended learning is a valuable approach of UNESCO to promote inclusive education especially to marginalised and vulnerable group. ${ }^{21}$

Theory is important for researchers, as proceeding without theory doesn't conduct top quality research. Concepts are the main building blocks of theory (Tehrani). ${ }^{22}$ Many of us are looking at hybrid work models in a new normal. It encourages interaction in a better way, as stated well by $\mathrm{Mr}$ Sanjay Lodha, Dean, Arts College Professor, that "Quality of E-content and increasing the platform of E learning has to be looked into seriously". 23,10

We have to think, what we want to keep, what we want to change and rework the future. ${ }^{23}$

\section{Limitations of study}

Few areas of concern were not described in the study like cost of internet and digital equipment used by student, different type of device used to attend online classes and speed of internet and related issues.

\section{CONCLUSION}

This study gives an in-depth insight into the current ongoing Online teaching methodologies from point of view of undergraduate medical students and how their experience is different from traditional teaching methodologies. As we develop the environment, we adjust our teaching methods. This is true for online learning. Now the question is how far can we go with online learning? The study throws light on changing acceptance of students to the current COVID-19 pandemic ways of teaching and their outlook and vision is broadened on welcoming a better "blended Learning" pattern in the upcoming post COVID-19 new normal times. There has always been growing demands for more flexible pathways to access quality higher education and lifelong learning opportunities for all. The study can be extended by including more pros and cons of online versus traditional teaching methods and by including more students' opinions from other medical colleges of different places as that would add a variety of ideas, preferences and 
experiences to account for and that will make the study broader and elaborated.

\section{ACKNOWLEDGEMENTS}

I would like to thank first year MBBS students of 2019 Batch of SPMC, Bikaner, Rajasthan, for participating in this study.

\section{Funding: No funding sources \\ Conflict of interest: None declared \\ Ethical approval: Not required}

\section{REFERENCES}

1. Sun A, Chen X. Online education and its effective practice: A research review. Journal of Information Technology Education Research. 2016;15:157-90.

2. Sagheb T. The results of Online teaching: A case study. Information Systems Education Journal. 2009;7(42).

3. Christner T. Review of Classroom of One: How Online Learning is Changing Schools and Colleges. Library Journal. 2003;128(1):130-1.

4. Carlson, S. After losing millions, Columbia University will close its online- learning venture. In: The Chronicle of High- er Education. 2003;49(19):A30.

5. Cheng J. Emergent E-Teaching Model For Traditional Brick-And-Mortar Higher Education Institutions. The IAB- PAD Conference Proceedings, Dallas, Texas. 2008;24-27.

6. Miller MT, Mei-Yan L. Serving Non-Traditional Students in E-Learning Environments: Building Successful Communities in the Virtual Campus. Educational Media International. 2003;40(1/2):163.

7. Dabal BD, Rathor RS, Bhargava VK, Ganesh N, Ritesh S, Ankita S. Student's perceptions and feedback about teaching-learning pharmacology in Nepalgunj medical college of Chisapani, Nepal. Int $\mathbf{J}$ Basic Clin Pharmacol. 2017;6(12):2789-93.

8. Mohan L, Chogtu B, Adiga S, Shenoy S, Bairy K, Kishore A. Undergraduate medical students' perceptions regarding personal drug selection exercise. Int J Pharm Clin Sci. 2012;1(2):61-7.

9. Research on the effectiveness of Online Learning. A compilation of research on online Learning, The future of State Universities. 2011.

10. Eric PB, Lindsay F, Susanna L, Eric ST. Virtual Classrooms: How Online College Courses affect Student success. American Economic Review. 2017;107(9):2855-75.

11. Gormley GJ, Collins K, Boohan M, Bickle IC, Stevenson M. Is There a Place for e-Learning in Clinical Skills? A Survey of Undergraduate Medical Students' Experiences and Attitudes. 2009;31(1):6-12.

12. Students, teachers not happy with Online classes: Survey, The Times Of India. Available at https://timesofindia.indiatimes.com/city/jaipur/studen ts-teachers-not-happy-with-online-classessurvey/articleshow/76414376.cms. Accessed on 20 September 2020.

13. Survey on online and Distance learning-Results. Available at https://www.schooleducationgateway.eu/en/pub/viewpoints/surveys/survey-ononline-teaching.htm. Accessed on 20 September, 2020.

14. Zeljka P, Blazenka k. E Learning: Survey on Student's opinion Proceedings of the ITI 2007. 29th Int. Conf. on Information Technology Interfaces. 2007.

15. Bhosale UA, Yegnanarayan R, Yadav GE. Attitude, perception and feedback of second year medical students on teaching learning methodology and evaluation methods in pharmacology: a questionnairebased study. Niger Med J. 2013;54:33.

16. Jai K, Abhishek S, Shwetank G, Aakansha G, Priyamvada S, Mirza URB, et al. Students' current perceptions and feedback on teaching and learning Pharmacology from an evolving medical school. International Archives of Integrated Medicine. 2015;2(7):99-104.

17. Suddenly online, A national survey of Undergraduates during COVID 19 Pandemic, Everywhere Learner Everywhere, Digital Promise. Available at https://digitalpromise.org/wpcontent/uploads/2020/07 /ELE_CoBrand_DP_FINAL_3.pdf. Accessed on 20 September 2020.

18. Anderson T. Modes of interaction in distance education: Recent developments and research questions. In M. Moore \& W. Anderson (Eds.), Handbook of distance education. Mahwah NJ: L. Erlbaum Associates. 2003;129-44.

19. Gillingham M, Molinari C. Online Courses: Student Preferences Survey. Internet Learning Fall. 2012;1(1):36-45.

20. Hiltz SR. The virtual classroom: Learning without limits via computer networks, Norwood, NJ. Ablex Publishing Corp. 2004.

21. Lim, Cher P, Wang, Libing. Selected Case studies on Implementation from Asia-Pacific, Education 2030. In: Blended Learning for Quality Higher Education.

22. Sagheb-Tehrani M. The Design Process of Expert Systems Development: Some Concerns, Experts Systems. The Journal of Knowledge Engineering. 2006;23(2):116-25.

23. Post COVID-19 pandemic: Hybrid-work model in the new-normal. Available at https://www.downtoearth.org.in/blog/governance/postCOVID-19pandemic-hybrid-work-model-in-the-new-normal73313. Accessed on 20 September 2020.

Cite this article as: Vijay R. Comparative evaluation of COVID-19 pandemic enforced online teaching versus traditional teaching from point of view of medical students. Int J Basic Clin Pharmacol $2021 ; 10: 36-43$. 